\title{
O NOVO CAMPO DE PÚBLICAS E O BRASIL DE HOJE
}

\section{Valdemir Pires e Rodrigo Horochovski}

Desde a Carta de Balneário Camboriú ${ }^{1}$, trazida a lume no IX ENEAP (à época, Encontro Nacional de Estudantes de Administração Pública), a certidão de nascimento do Campo de Públicas, enquanto movimento, transcorreram sete anos. Pouco tempo, que não passou rápido cronologicamente (como poderia?), mas voou psicossocialmente (numa aproximação coletiva do que chamam "tempo psicológico"). Todos que militam no Campo de Públicas, como estudantes, professores, pesquisadores ou profissionais, devem ter a sensação de que esses sete anos foram, ao menos, vinte e um, para multiplicá-los apenas por três, sem pretensões kubitschekianas.

De 2010 a 2017 o Campo de Públicas passou de meia dúzia de entusiastas acadêmicos a um movimento nacional sólido, cujas primeiras grandes conquistas foram as Diretrizes Curriculares Nacionais ( $\left.\mathrm{DCNs}^{2}\right)$ próprias para os cursos que o compõem e o Exame Nacional de Cursos (ENADE) específico.

Nesse setênio surgiram e passaram atuar vigorosamente as entidades do Campo de Públicas, cada qual com sua especificidade e dinâmica própria, juntando-se à precursora FENEAP (Federação Nacional dos Estudantes dos Cursos do Campo de Públicas): ANEPCP (Associação Nacional de Ensino e Pesquisa do Campo de Públicas), SBAP (Sociedade Brasileira de Administração Pública), Pró-Publica Brasil (Associação Brasileira dos Profissionais do Campo de Públicas), Fundo do Campo de Públicas. Os eventos da área de multiplicaram e se sofisticaram, passando a existir os de caráter científico, liderados pelas entidades, e disseminaram-se os ERECAPs (Encontros Regionais do Campo de Públicas - Sul, Norte/Nordeste, Paulista, Mineiro). Muitas e expressivas lideranças emergiram de norte a sul do país, nesse processo.

\footnotetext{
${ }^{1}$ Disponível em: https://psigma.files.wordpress.com/2010/08/carta-de-bal_-camboriu.pdf

2 Disponível em:

http://portal.mec.gov.br/index.php?option=com_docman\&view=download\&alias=14957rces001-14\&Itemid=30192
} 
Talvez os protagonistas não se dêem conta da enormidade do feito: estão materializando algo que o país nunca teve, para azar dele e de Vargas e seu grupo, quando deram início à constituição de um Estado burocrático moderno, com sua administração pública profissional e com sentido de missão (tanto quanto possível em meio a tanto patrimonialismo, que ainda persiste). À era Vargas faltaram, sem dúvida, além de cidades e indústrias, uma capacidade profissional instalada ou em produção (nas escassas universidades) de gestores públicos com competência técnica: às ideias e objetivos daspianos faltavam cérebros e braços, além de um ethos.

A partir do Campo de Públicas pode-se afirmar com segurança que o Brasil caminha a passos largos para um histórico singular de constituição de uma força de trabalho para atuação nos governos, em seus diferentes níveis e esferas, com formação superior invulgar, dada sua multidisciplinaridade e seus valores democráticos e republicanos, concatenada na graduação e na pósgraduação.

Infelizmente, entretanto, também o Brasil mudou aceleradamente nos últimos sete anos. Desafortunadamente, para muito pior. Aquela Nação que brilhava no cenário internacional no começo da segunda década do século XXI, por seus feitos em termos de desenvolvimento econômico e distribuição de renda, de fortalecimento institucional e inserção na economia e na diplomacia mundiais, de democracia e accountability, de avanços civilizatórios, enfim, aquela Nação parece ter derretido ao caminhar para o final da década de 2010, engolida por uma crise econômica e política (combinadas) das piores da História nacional. Ninguém sabe dizer a que ponto se chegará, a persistirem, a cada semana ou mês, os novos lances da cizânia que parece ter fincado pé, definitivamente, no Brasil, desde o dia de Santo Antônio de 2013, desde os desgastes das eleições de 2014 e desde o impeachment de Dilma Roussef, em 2016.

Essa circunstância complexa, combinando, de um lado, retrocessos na sociedade, na economia e no Estado brasileiros e, de outro lado, avanços antes impensáveis na geração de competência tecnopolítica de nível superior para dar conta da administração pública, dos serviços públicos e das políticas públicas, 
exige do Campo de Pública e de suas entidades um esforço analíticos e de articulação para que ele próprio não seja tragado pela crise, para que não morra na praia dos afogados pela tragédia da crise gêmea, em parte autóctone, em parte trazida pelas embarcações globais diante das quais somos chamados de bárbaros - sim, porque nesses tempos pós-modernos os invasores é que são os "civilizados", com suas sofisticada maquinaria leve e lépida de intrusão e abdução.

Muitas perguntas de difícil resposta se colocam ao Campo de Públicas e suas entidades neste momento, não sendo suficiente repetir os bordões consagrados da profissionalização e as palavras-de-ordem contra o patrimonialismo que, de resto, só fez se aprofundar sistemicamente, depois de ter sido flagrado aqui e ali. Perguntas como:

De que modo assegurar a atratividade dos cursos de graduação e pósgraduação num cenário de desprestígio da Política e de recuo programático da atuação estatal e de encurralamento financeiro dos governos?

Que formação oferecer aos futuros gestores públicos, nos níveis de graduação e pós-graduação, para que tenham um perfil ao mesmo tempo cosmopolita e nacional/regionalmente sensível, cientificamente embasado e socialmente engajado, politicamente preparado e tecnicamente bem-dotado?

Por que meios e com que argumentos combater a reversão do robustecimento institucional verificado nas últimas décadas na direção da transparência, da participação popular, dos direitos sociais e das políticas públicas?

Como contribuir para que as saídas oferecidas para a crise fiscal (em particular) e econômica (em geral) não destruam a soberania nacional, a capacidade governamental de decidir e agir em favor da população e a possibilidade de um projeto de Nação capaz de evitar sua erosão pelos interesses avassaladores da globalização financeira?

Essas perguntas, entre outras de semelhante envergadura, devem ser respondidas coletivamente pelo movimento Campo de Públicas e por suas entidades, estas nos respectivos âmbitos de sua responsabilidade (ensino, pesquisa, extensão, inserção profissional, financiamento de atividades etc.); 
aquele, de modo geral (projeto democrático, republicano, tecnopolítico e multidisciplinar, voltado ao desenvolvimento sustentável e à superação das desigualdades configurado pelas DCNs próprias do Campo de Públicas).

A temporada intensa de debate e articulação está aberta e seu lema é muito antigo: "Decifra-me ou devoro-te". O enigma é duplo:

1. qual o modelo de Estado e que padrões de governos e federalismo são necessários, hoje, para a retomada do desenvolvimento, com robustecimento das instituições democráticas e redução das desigualdades, no Brasil?;

2. que papel poderá/deverá ter na busca desse modelo e padrões o Campo de Públicas, enquanto movimento e enquanto um conjunto de entidades? 